\title{
PETUNJUK BAGI PENULIS
}

Bagi Penulis yang berkeinginan untuk artikelnya diterbitkan pada Jurnal Riset dan Konseptual BRILIANT harus petuntuk sebagai berikut:

1) Artikel adalah asli ditulis oleh penulis dan bebas dari plagiasi serta belum pernah diterbitkan sebelumnya.

2) Penulisan artikel harus sesuai dengan tatacara penulisan artikel ilmiah untuk jurnal, terdapat pada buku Pedoman Penulisan Karya Ilmiah yang diterbitkan oleh Universitas Nahdlatul Ulama Blitar.

3) Artikel yang dimuat dalam Jurnal ini adalah Artikel hasil penelitian dan artikel non penelitian (Konseptual)

4) Artikel ditulis dengan program Microsoft Word, Jenis Huruf: Times New Roman, Ukuran 12 pt, spasi: single 0 pt. Ukuran kertas A4.

5) Artikel ditulis dengan jumlah halaman sekurang-kurangnya 12 halaman dan maksimal 20 halaman.

6) Judul artikel ditulis secara spesifik dengan jumlah tidak lebih dari 15 kata.

7) Identitas penulis ditulis dengan nama lengkap tanpa disertai gelar diikuti dengan alamat lembaga dan email penulis dibawahnya. Bagi penulis yang jumlahnya lebih dari satu, pada bagian akhir nama masing-masing penulis diberi kode alamat korespondensi. Alamat korespondensi berisi alamat lembaga dan email penulis. Dapat dicontohkan sebagai berikut,

Adia Syahrani ${ }^{(1)}$, Gatot Wiwaha ${ }^{(2)}$, Muhammad Umar ${ }^{(3)}$

${ }^{1}$ Mahasiswa Program Studi PGSD, Universitas Nahdlatul Ulama Blitar,

${ }^{2,3}$ Dosen Prodi PGSD, Universitas Nahdlatul Ulama Blitar

Email: ${ }^{1}$ adiasyah@ gmail.com, ${ }^{2}$ gatot.pgsd@gmail.com, ${ }^{3}$

mu_umar90@gmail.com.

8) Artikel dilengkapi dengan abstrak yang ditulis dalam bahasa Indonesia sebanyak maksimal 150 kata. Abstrak menggambarkan latar belakang, rumusan masalah, teori, hipotesis, metode dan hasil penelitian.

9) Batang tubuh artikel penelitian sebagai berikut

\section{PENDAHULUAN}

Kata pendahuluan tidak perlu ditulis. Pendahuluan pada artikel memuat empat gagasan, yaitu: (a) latar belakang penelitian, (b) masalah dan wawasan rencana pemecahan masalah, (c) solusi yang ditawarkan, (d) pembahasan singkat tengang solusi (d) tujuan dan harapan tentang manfaat hasil penelitian. Pencantuman istilah Pendahuluan berposisi sebagai subjudul yang mengawali isi artikel. Oleh karena itu, istilah Pendahuluan tidak dapat diganti oleh atau diberi subjudul lagi. Posisi Pendahuluan, ditulis langsung setelah abstrak.

Pada bagian pendahuluan ini diintegrasikan ringkasan isi latar belakang/konteks penelitian, rumusan masalah/fokus penelitian, tujuan dan manfaat penelitian, ruang lingkup, dan kajian pustaka. Untuk menjamin 
originalitas tulisan dan otoritas penulisnya, pada bagian pendahuluan ini harus disertai rujukan dalam jumlah yang proporsional (tidak terlalu banyak atau tidak terlalu sedikit), ringas, padat, dan langsung pada persoalannya. Sajian informasi di dalamnya diarahkan pada tampilan hakikat masalah, rancangan pemecahan masalah, dan rumusan tujuan dilakukan penelitian. Misalnya, kerangka teoretiknya, kajian riset sebelumnya (terdahulu), aspek historisnya, dan lainnya. Kutipan ahli diperlukan untuk ditulis dalam bab ini.

\section{METODE}

Bagian ini menyajikan secara ringkas tentang bagaimana penelitian dilakukan. Uraian disajikan dalam beberapa paragraf tanpa subbagian atau dipilah-pilah dalam subsubbagian. Isinya, menyangkut teknik pengumpulan data, subjek/sampel, instrumen pengumpulan data, sumber data, dan teknik analisis data. Kutipan ahli tentang metode penelitian diperbolehkan untuk ditulis. Agar menghindari penggunaan tabel, dan lebih mengutamakan penulisan dalam bentuk deskriptif.

\section{HASIL}

Bagian ini menyajikan hasil-hasil analisis data dan hasil pengujian hipotesis yang bertujuan di antaranya: (a) menjawab masalah penelitian atau menunjukkan bagaimana tujuan itu dicapai, (b) menafsirkan temuan-temuan. Dianjurkan untuk memberi sub - sub judul untuk masing-masing temuan penelitian. Agar menghindari penggunaan tabel dan lebih mengutamakan penulisan dalam bentuk deskriptif.

\section{PEMBAHASAN}

Pada bagian pembahsan ini hasil penelitian yang diperoleh diintegrasikan ke dalam kumpulan pengetahuan dan teori yang telah mapan, dan menyusun teori baru atau memodifikasi teori yang ada. Kutipan ahli diperlukan dalam bab ini. Dianjurkan untuk memberi sub - sub judul untuk masing-masing temuan penelitian. Agar tidak menggunakan tabel dan lebih mengutamakan penulisan dalam bentuk deskriptif.

\section{KESIMPULAN}

Kesimpulan menyajikan hasil dari pembahasan terhdap temuan penelitian. Kesimpulan disajikan dalam bentuk essei, bukan dalam bentuk numerikal.

\section{SARAN}

Saran disusun berdasarkan kesimpulan yang telah ditarik. Saran mengacu pada tindakan praktis, atau pengembangan teoretis, dan penelitian lanjutan

10) Batang tubuh artikel non penelitian (konseptual) sebagai berikut:

\section{PENDAHULUAN}

Kata pendahuluan tidak perlu ditulis. Pendahuluan pada artikel memuat empat gagasan, yaitu: (a) latar belakang penelitian, (b) masalah dan wawasan rencana pemecahan masalah, (c) solusi yang ditawarkan, (d) pembahasan singkat tengang solusi (d) tujuan dan harapan tentang manfaat hasil penelitian. Pencantuman istilah Pendahuluan berposisi sebagai subjudul yang mengawali isi 
artikel. Oleh karena itu, istilah Pendahuluan tidak dapat diganti oleh atau diberi subjudul lagi. Posisi Pendahuluan, ditulis langsung setelah abstrak.

Pada bagian pendahuluan ini diintegrasikan ringkasan isi latar belakang, masalah, tujuan dan manfaat kajian, ruang lingkup, dan kajian pustaka. Untuk menjamin originalitas tulisan dan otoritas penulisnya, pada bagian pendahuluan ini harus disertai rujukan dalam jumlah yang proporsional (tidak terlalu banyak atau tidak terlalu sedikit), ringas, padat, dan langsung pada persoalannya. Kutipan ahli diperlukan untuk ditulis dalam bab ini.

\section{PEMBAHASAN}

Pada bagian pembahsan ini, dibahas kajian - kajian terhadap masalah serta solusinya dan diintegrasikan ke dalam kumpulan pengetahuan dan teori yang telah mapan, dan menyusun teori baru atau memodifikasi teori yang ada. Kutipan ahli diperlukan dalam bab ini. Dianjurkan untuk memberi sub - sub judul untuk masing-masing temuan penelitian. Agar menghindari penggunaan tabel dan lebih mengutamakan penulisan dalam bentuk deskriptif.

\section{KESIMPULAN}

Kesimpulan menyajikan hasil dari pembahasan. Kesimpulan disajikan dalam bentuk essei, bukan dalam bentuk numerikal.

\section{SARAN}

Saran disusun berdasarkan kesimpulan yang telah ditarik. Saran mengacu pada tindakan praktis, atau pengembangan teoretis, dan kajian lanjutan.

11) Agar lebih mudah dalam penulisan artikel, baik penelitian maupun non penelitian dapat mengunduh template artikel yang tersedia di www.jurnal.unublitar.ac.id/index.php/briliant

12) Pada akhir penulisan artikel, ditulis daftar rujukan dari artikel tersebut. Daftar rujukan artikel sekurang-kurangnya 15 rujukan.

13) Cara menulis rujukan menggunakan harvard style, diurutkan berdasrkan abjad terdepan nama penulis sumber rujukan. Format penulisan rujukan dicontohkan sebagai berikut:

\section{Buku}

Majid, Abdul. 2014. Strategi Pembelajaran. Bandung: Remaja Rosdakarya.

\section{Artikel jurnal tercetak}

Zainuddin. 2016. Designing Scientific Learning Model Application in Lowgrade of Primary Schools Based on the 2013 Curiculum in East Java, Indonesia. Journal of Social Science (COES\&RJ-JSS), 5 (3): 229237.

\section{Artikel Jurnal elektronik}

Putri, Noviani Achmad. 2011. Penanaman Nilai-nilai Pendidikan Karakter melalui Mata pelajaran Sosiologi . Komunitas, (Online), 3 (2): 201- 
215, (http://journal.unnes.ac.id/nju/index.php/komunitas/article/ download/2317/2370), diakses tanggal 23 Juli 2016.

\section{Dokumen yang diterbitkan Pemerintah atau Lembaga tertentu}

Kementerian Pendidikan dan Kebudayaan. 2012. Dokumen Kurikulum 2013. Jakarta Kemeneterian Pendidikan dan Kebudayaan RI

\section{Artikel Media Masa}

Tanpa Nama. Juli 2016. Pendidikan Karakter. Aula, hlm. 7.

\section{Makalah Seminar}

Akbar, Sa'dun. 2016. Riset Pengembangan untuk Pengembangan Alat Pembelajaran. Makalah disajikan dalam Lokakarya Penyusunan Proposal Penelitian Didanai DRPM DIKTI, FIP UM, Malang, 2 Mei 2016.

14) Penulisan Tabel disesuaikan dengan kebutuhan dan mengikuti tata cara yang telah ditentukan pada buku Pedoman Penulisan Karya Ilmiah yang diterbitkan oleh Universitas Nahdlatul Ulama Blitar. Diharapkan penulis untuk meminimalisir penggunaan tabel dalam artikel.

15) Artikel yang ingin diterbitkan harus dimasukkan ke Jurnal Riset dan Konseptual Briliant secara online dengan fasilitas register/login di http://jurnal.unublitar.ac.id/index.php/briliant. File yang dimasukkan bereksistensi microsoft office 2003 (.doc).

16) Artikel yang dikirim hendaknya disesuaikan dengan petunjuk yang ada atau disesuaikan dengan template yang terdapat di http://jurnal.unublitar.ac.id/index.php/briliant.

17) Artikel yang masuk akan disunting oleh dewan editorial untuk kemudian diputuskan dapat di terbitkan atau tidak serta akan disampaiakn ketentuan yang harus dilakukan oleh penulis agar dapat diterbitkan. diharapkan penulis secara aktif melakukan pemantauan perjalanan artikel yang dimasukkan dengan login di http://jurnal.unublitar.ac.id/index.php/briliant melalui akun yang digunakan untuk memasukkan artikel.

18) Penyuntingan tidak merubah substansi pokok dari artkel yang ditulis. Serta hak cipta artikel menjadi milik Penulis, Tim redaksi maupun penyunting tidak bertanggungjawab bila ditemukan plagiasi dalam artikel tersebut.

19) Bagi penulis yang artikelnya memenuhi kriteria dan layak diterbitkan akan dikonfirmasi oleh tim redaksi. 